http://e-journal.stit-islamic-village.ac.id/index.php/JM2PI

\title{
Pengaruh Perilaku Bullying Terhadap Kepercayaan Diri Siswa Kelas Viii Mts Esa Nusa Islamic School Binong - Tangerang
}

\author{
Siti Komala Sari \\ Program Studi Pendidikan Agama Islam, STIT Islamic Village Tangerang \\ Email: komalasarisiti155@gmail.com
}

Received: September, 2020.

Accepted: Oktober, 2020.

Published: November, 2020

\begin{abstract}
The problem in this research is that there are cases of bullying behavior committed by students against their own friends. Like mocking friends, calling their parents, so that makes someone feel annoyed. This study was conducted to determine how much influence bullying behavior has on the confidence of grade VIII students of MTs Esa Islamic School Binong-Tangerang for the 2019-2020 academic year.

This type of research is quantitative correlational research with a sample of 49 students. The sampling technique uses non-probability sampling (it does not provide the same opportunity to the population) to determine the number of samples taken, namely the census technique because the population is less than 100 so all populations can be used as samples.

The instrument used for the study has been tested for validity and the researcher uses 20 valid statements. Reliability test uses the Alpha Cronbach formula in the SPSS application so that the results of $r$ count $(0.622)>r$ table $(0.281)$ for bullying instruments and $r$ count $(0.677)>r$ table $(0.281)$ for self-confidence instruments, so the instrument is declared reliable.

The results of this research hypothesis test are: (1) The level of bullying (bullying behavior) in class VIII students of MTs Esa Nusa Islamic School BinongTangerang for the 2019-2020 school year is in the strong category with a percentage of $47.6 \%$. (2) obtained the results of $r$ count $(0.690)>r$ table $(0.281)$ then Ho is rejected and $\mathrm{Ha}$ is accepted. This means that bullying behavior has an influence on student self-confidence, meaning that if the higher the intensity of bullying in students, the lower the self-confidence in students, and vice versa.
\end{abstract}

Keywords: Bulying, Self Confidence.

\section{ABSTRAK}

Dari hasil penelitian yang dilakukan, yaitu mengenai pengarub perilaku bullying terhadap kepercayaan diri siswa menjadi Masalah dalam penelitian ini adalah adanya kasus perilaku bullying yang dilakukan oleh siswa terhadap temannya sendiri. Seperti mengejek teman, memanggil memakai sebutan nama orang tuanya, sehingga membuat seseorang merasa terganggu. Penelitian ini dilakukan yang memiliki tujuan untuk mengetabui sumbang pengaruh dari 
Pengaruh Perilaku Bullying Terhadap Kepercayaan Diri Siswa Kelas Viii Mts Esa Nusa Islamic School Binong - Tangerang

perilaku bullying terhadap kepercayaan diri siswa kelas VIII MTs Esa Islamic School BinongTangerang Tahun pelajaran 2019-2020.

Peneliti menggunakan jenis penelitian Kuantitatif koralasional menggunakan sampel sebanyak 49 siswa. Teknik pengambilan sampel menggunakan Non-probality sampling (tidak memberikan peluang yang sama kepada populasi) untuk menentukan jumlah sampel yang diambil yaitu dengan teknik sensus dikarenakan jumlab populasi dibawah 100 maka semua populasi dapat digunakan sebagai sampel. Intrumen yang dipakai untuk penelitian telah diuji validitasnya dan peneliti menggunakan 20 butir pernyataan yang telah valid. Rumus Alpha Cronbach pada aplikasi SPSS digunakan untuk Uji reliabilitas sehingga diperoleh hasil $r$ bitung $(0,622)>r_{\text {tabel }}(0,281)$ untuk instrumen bullying $r_{\text {bitung }}(0,677)>r_{\text {tabel }}(0,281)$ untuk instrumen kepercayaan diri, maka instrumen dinyatakan reliabel.

Hasil dari uji hipotesis yaitu: (1) Tingkat Perundungan (perilaku bullying) pada siswa kelas VIII MTs Esa Nusa Islamic School Tangerang Tabun ajaran 2019-2020 tergolong dalam kategori kuat dengan prosentase 47,6\%. (2) diperoleh hasil $r$ bitung $(0,690)>r$ tabel (0,281) maka Ho ditolak dan Ha diterima. Artinya perilaku bullying memiliki pengarub terbadap kepercayaan diri siswa, artinya jika semakin tinggi instensitas bullying pada siswa maka semakin rendah kepercayaan diri pada siswa, begitupun sebaliknya.

\section{Kata Kunci: Bulying, Kepercayaan Diri}

\section{PENDAHULUAN}

Banyak masalah yang terjadi di masa saat ini mengenai kekerasan, yang dialami oleh diri sendiri maupun yang dialami oleh orang lain, pastinya orang yang mengalami hal tersebut akan merasakan sakit secara fisiknya maupun gangguan secara psikis dan mental pada jiwa seseorang. Tindakan kekerasan ini banyak sekali dialami, khususnya yang sering sekali terjadi dikalangan remaja, hal demikian akan terjadi baik di kalangan rumah maupun di kalangan pendidikan atau sekolah.

Bullying merupakan suatu tindakan dan ucapan yang akan menimbulkan rasa sakit atau takut maupun perasaan tertekan pada jiwa seseorang, karena hal ini juga dilakukan dengan sengaja. Bullying merupakan masalah yang sangat serius, kebanyakan hal seperti ini sering sekali ditemukan di kalangan remaja. Dan pengaruh bullying akan sangat merusak pada aspek kehidupan.

Dimasa sekarang sudah banyak sekali Pemberitaan mengenai tindakan bullying tersebut. Baik pemberitaan secara langsung maupun di media sosial. Adanya tindakan bullying terutama dilingkungan institusi pendidikan. Dan kebanyakan tindakan bullying tersebut dikalangan remaja yang menimpa teman sebaya, antara junior dan senior, dimana mereka yang seharusnya fokus saja pada pendidikan namun hal seperti ini sering muncul dan membuat korban bullying menjadi sangat risih dan kepercayaan diri seseorang akan terganggu. Biasanya objek atau sasaran korban bullying akan 
berimbas kepada orang yang lebih lemah dari pada orang yang melakukan tindakan bullying tersebut.

Tindakan bullying tidak hanya dalam bentuk verbal, seperti mengejek, menghina temannya, namun tindakan bullying juga bisa dilakukan dengan cara fisik seperti memukul, yang pada akhirnya kan membuat korban menjadi lemah dalam kesehatan mentalnya, dan kemungkinan besar akan membuat seseorang bisa mengalami trauma pada dirinya.

Meski demikian hal ini sangatlah merugikan korban, karena tidak hanya sakit pada fisiknya saja, namun psikologi korban bully juga akan terganggu. Tindakan yang dialaminya dalam berita juga menyatakan bahwa SM sempet histeris, dirinya merasakan perasaan trauma dan ketakutan, namun seiring dengan berjalannya waktu, dengan terus-menerus diajak untuk berkomunikasi pelan-pelan MS hanya mengaku bahwa dia mendapat perlakuan yang tidak menyenangkan di sekolah. Yang diungkapkan MS bahwa dirinya dijatuhkan oleh temannya, adanya perlakuan-perlakuan yang tidak mengenakan kepada dirinya. sehingga saat ini dirinya membutuhkan proses untuk mengembalikan rasa takut dan cemas dalam dirinya.

Hal ini merupakan dampak dari tindakan Bullying yang sangat memengaruhi pada psikologi seseorang, terutama dalam hal kepercayaan diri, sehingga dapat memengaruhi pola pikir, dan perilaku korban bullying yang memiliki keyakinan negatif seseorang terhadap kekurangan dalam dirinya, sehingga hal ini membuat seseorang merasa bahwa untuk mencapai berbagai tujuan dalam kehidupannya dirinya merasa tidak mampu.

\section{KAJIAN TEORI}

Definisi bullying Menurut Kamus Besar Bahasa Indonesia (KBBI) yaitu suatu bentuk penindasan, perundungan, perisakan atau pengintimidasian dengan menggunakan kekerasan, ancaman, atau paksaan untuk menyalah gunakan atau mengintimidasi orang lain. Secara umum diartikan sebagai bentuk dari perilaku agresif yang disengaja karena kekuatan tersebut dominan pada perilaku sehingga dilakukan secara berulang-ulang dengan tujuan untuk mengganggu seseorang yang dianggap lebih lemah dari padanya (Nurdin, 2019).

Menurut coloroso bullying diartikan sebagai tindakan intimidasi yang dilakukan secara berulang-ulang oleh pihak yang lebih kuat terhadap pihak yang dianggap lebih lemah dari padanya, sehingga pelaku tersebut sengaja dan memiliki tujuan membuat korban terluka secara fisiknya atau secara emosional. 
Diartikan juga sebagai perilaku yang sangat tidak baik dan tidak senonoh yang dilakukan dengan sengaja untuk membuat seseorang yang dianggapnya lebih lemah dan menyakitinya, dengan tindakan yang bisa dilakukan dengan cara berwujud fisik, verbal dan juga psikologis (Evra Wilya, 2018).

Dapat diambil kesimpulan, bahwa Perundungan (bullying) merupakan perilaku yang dapat merugikan seseorang secara berulang karena adanya perbedaan kekuatan maupun kekuasaan yang tidak seimbang. Tindakan yang sengaja ini dilakukan untuk menyakiti seseorang atau membuat orang lain tidak nyaman karena dilakukan cara terus-menerus, yang bisa dilakukan dengan cara tindakan kekerasan fisik, secara verbal, maupun tindakan untuk mengganggu psikologis seseorang.

\section{Bentuk-bentuk perilaku Bullying}

Adapun bentuk-bentuk perilaku bullying di lingkungan pergaulan maupun lingkungan sekolah sangat beragam macamnya. Bullying Secara umum dapat dibagi menjadi 3 kategori, yaitu: bullying secara fisik, bullying non fisik (verbal) dan bullying secara Psikologis.

a. Bullying secara fisik

Suatu aksi yang disengaja untuk menyakiti seseorang yang menjadi korban bullying atau perundungan dengan cara memukul, menendang, menampar, mencekik, menggigit, mencakar, meludahi, dan merusak serta barang-barang milik individu atau korban dari bullying dihancurkan.

b. Bullying secara verbal (Non Fisik)

Suatu tindakan atau perilaku yang menyakiti seseorang dengan cara mengejek, memberi julukan nama, fitnah, kritikan kejam, penghinaan, pernyataan-pernyataan yang bernuansa ajakan atau pelecehan seksual, surat-surat yang mengintimidasi, adanya tuduhan-tuduhan yang tidak benar, kasak kusuk yang keji dan keliru, gosip dan sebagainya.

c. Bullying secara Relasional

Perilaku yang dilakukan secara sistematis untuk melemahkan harga diri seseorang atau sebagai korban dengan cara mengabaikan, tindakan untuk mengucilkan dan menghindari seseorang. Hal tersebut juga dapat mencakup sikap-sikap seperti melakukan pandangan yang agresif, lirikan mata, helaan napas, cibiran, kemudian tertawa untuk mengejek, serta dari bahasa tubuh yang menghina, dan lain sebagainya.

d. Bullying secara Elektronik 
Melakukan penindasan melalui sarana elektronik yang bertujuan untuk menyakiti seseorang di dunia maya atau media sosial (Adhiatma \& Christianto, 2019)

Baik anak laki-laki maupun perempuan dapat melakukan aksi bullying dengan secara langsung maupun tidak langsung, biasanya yang lebih banyak menggunakan jenis bullying fisik adalah anak laki-laki, dan jenis bullying relasional atau pengucilan sosial lebih banyak pada anak perempuan.

\section{Faktor terjadinya Perilaku bullying}

Adapun alasan atau faktor melakukan perundungan (bullying) yaitu:

a) Faktor Keluarga

Faktor bullying sering sekali terjadi karena dari lingkungan keluarga yang bermasalah, contohnya sering menghukum anaknya secara berlebihan, atau situasi rumah yang kurang harmonis. Maka seorang anak akan tanggap dan mengikuti perilaku bullying ketika dirinya mengamati dan mengalami masalah yang ada di lingkungan rumahnya atau yang terjadi pada orang tua mereka, sehingga dirinya dapat meniru dan melakukannya dihadapan teman-temannya (Zakiyah et al., 2017)

b) Faktor likungan Sekolah

Adanya pihak sekolah yang sering mengabaikan keberadaan tindakan bullying. Sehingga mengakibatkan siswa akan sebagai pelaku bullying ini akan mendapatkan penguatan terhadap mereka yang ingin melakukan aksi untuk membuat orang lain tersakiti. Kemudian adanya pihak sekolah kemungkinan sering memberikan hukuman kepada siswanya yang tidak mendidik atau tidak membangun pada karakter baik siswa, sehingga tidak membangun rasa untuk menghormati dan menghargai pada sesama anggota di sekolah.

c) Faktor Kelompok Sebaya

Ketika anak-anak dalam berinteraksi dengan temannya baik di sekitar rumah maupun di sekolah, terkadang mereka terdorong untuk melakukan tindakan yang senonoh. Ada beberapa anak yang melakukan tindakan bullying, itu karena ingin membuktikan bahwa mereka bisa masuk dalam kelompok tertentu, meskipun mereka sendiri sebenarnya tidak nyaman dengan perilaku tersebut.

d) Lingkungan Sosial 
Dalam kondisi lingkungan dapat memengaruhi terjadinya perilaku bullying. Salah satunya yaitu faktor kemiskinan. Mereka yang hidup dalam kemiskinan itu akan melakukan apapun untuk memenuhi kebutuhannya, sehingga banyak sekali hal yang terjadi di sekolah seperti pemalakan terhadap temannya (Zakiyah et al., 2017)

e) Tayangan Media Sosial

Adanya kekerasan yang muncul di Media sosial juga berpengaruh besar pada sikap seseorang, seperti sinetron atau film, game, bahkan berita tentang kekerasan fisik, sehingga membuat seseorang yang kepribadiannya belum stabil dapat menyerap bahkan ingin melakukannya. (Titi Keke, 2019). Dimana saat ini media sosial sudah menjadi bagian dari kehidupan manusia. Melalui media cetak maupun media elektronika maka akan ada dampak yang ditimbulkan untuk perilaku seseorang dengan kemungkinan ada yang baik atau tidak.

Kepercayaan diri merupakan salah satu sifat kepribadian yang menggabungkan pikiran dan perasaan, perjuangan, dan harapan, ketakutan dan fantasi, atau sikap individu yang berkaitan dengan kemampuannya. Percaya diri juga dapat didefinisikan sebagai suatu sikap atau keyakinan yang kuat terhadap kemampuan yang dimiliki sehingga dapat melakukan sesuatu yang dapat dimanfaatkan dengan cara yang tepat. (Jusuf Blegur, 2020)

Kepercayaan diri juga merupakan suatu sikap seseorang yang positif sehingga memampukan dalam pengembangan nilai yang positif terhadap diri sendiri, lingkungan atau keadaan yang dihadapinya (Fauziah, 2017). Dalam Q.S Ali-Imran Ayat 139 Allah SWT berfirman:

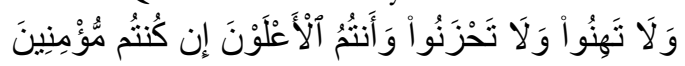

"Janganlah kamu bersikap lemah, dan janganlah (pula) kamu bersedih hati, padahal kamulah orang-orang yang paling tinggi (derajatnya), jika kamu orang-orang yang beriman"

Melalui ayat tersebut dapat kita pahami bahwasannya Allah tidak menyukai dengan orang yang mempunyai sifat lemah, perlu adanya sikap yang optimis dalam menjalani kehidupan, maka dalam menjalani kehidupan sehari-hari untuk bersikap percaya diri sangatlah penting yang 
digunakan sebagai modal untuk menapaki kehidupan yang terus berkembang.

Menurut Afiatin dan Andayani (Komara, 2016) kepercayaan diri merupakan aspek kepribadian yang berisi keyakinan tentang kekuatan dalam dirinya, serta kemampuan dan keterampilan yang dimilikinya. Adapun pengertian menurut Willis, bahwa kepercayaan diri merupakan sikap seseorang yang mampu dan yakin untuk menanggulangi masalah dengan situasi terbaik, dan juga dapat memberikan sesuatu yang dapat menyenangkan untuk orang lain (Komara, 2016).

Dapat disimpulkan bahwa kepercayaan diri adalah suatu keyakinan yang dimiliki oleh seseorang terhadap aspek yang dimilikinya, sehingga dirinya merasa mampu, nyaman, serta puas dengan diri sendiri, sehingga dengan keyakinan pada aspek tersebut akan membuat dirinya merasa mampu untuk mengatasi dan mengembangkan segala situasi dengan positif, dan dirinya juga akan merasa mampu untuk mencapai berbagai macam tujuan dalam hidupnya.

\section{Ciri-ciri Pribadi dengan kepercayaan diri}

Berikut ini terdapat beberapa karakteristik atau ciri-ciri untuk menilai kepercayaan diri pada individu yang proporsional, diantaranya:

a. Sikap Percaya terhadap kompetensi dirinya

b. Memiliki sikap yang optimis

c. Pantang menyerah

d. Dapat menyesuaikan diri dengan orang lain

e. Dapat mengendalikan diri dengan baik (memiliki emosi yang stabil)

f. Tidak mudah bergantung atau mengharapkan bantuan dari orang lain

g. Memiliki cara pandang yang positif, baik terhadap dirinya, orang lain, maupun pada situasi lain.

h. Kelebihan yang dimilikinya dapat dimanfaatkan dengan baik. (Fauziah, 2017)

\section{METODE}

Dengan menggunakan Metode kuantitatif Korelasional (Mencari hubungan antara variabel X dengan variabel Y), Teknik pengambilan sampel dengan menggunakan teknik non-probality sampling (tidak memberikan peluang yang sama kepada populasi), untuk menentukan jumlah sampel menggunakan teknik sensus, karena populasi dalam penelitian ini kurang dari 100 maka populasi dapat dijadikan sebagai sampel yang berjumlah 49 orang. Sebagai 
Responden yaitu peserta didik kelas VIII MTs Esa Nusa Islamic School Binong-Tangerang, sedangkan objek penelitian ini adalah Pengaruh perilaku bullying terhadap kepercayaan diri siswa. Teknik yang digunakan untuk pengumpulan data penelitian yaitu: Teknik Observasi, teknik Angket/Kuesioner, teknik dokumentasi.

\section{HASIL DAN PEMBAHASAN}

Penelitian ini dilakukan untuk mengetahui ada atau tidaknya pengaruh dari perilaku bullying terhadap kepercayaan diri siswa kelas VIII MTs Esa Nusa Islamic School Binong- Tangerang.

Untuk mengetahuinya, telah disebutkan bahwa terdapat Hipotesis yang masih harus diuji kebenarannya yakni:

Ha: Perilaku bullying memiliki pengaruh yang signifikan terhadap

kepercayaan diri siswa kelas VIII MTs Esa Nusa Islamic School Binong-Tangerang.

H0: Perilaku bullying tidak memiliki pengaruh yang signifikan terhadap

kepercayaan diri siswa kelas VIII MTs Esa Nusa Islamic School Binong-Tangerang.

Peneliti mendapatkan hasil yang berdistribusi normal berdasarkan penelitian yang telah dilakukan. Berikut ini gambar dan penjelasannya.

\section{Gambar 1. Histogram Uji Normalitas}

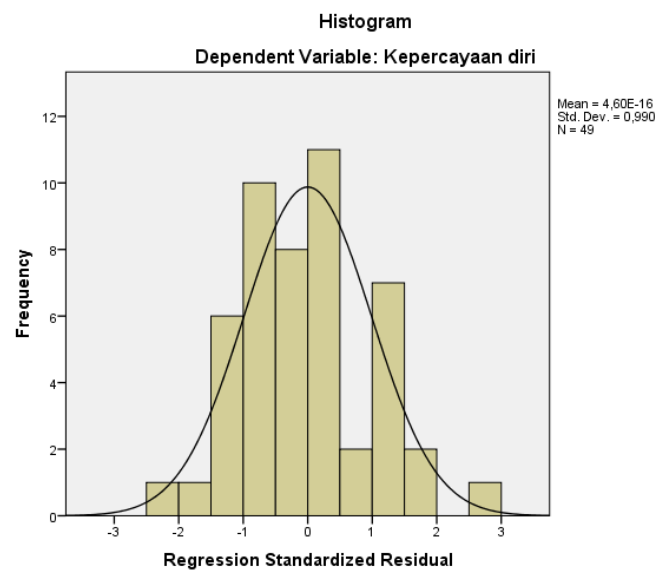

Berdasarkan gambar di atas, dapat disimpulkan bahwa data penelitian berdistribusi normal, dan grafik histogram tersebut menggambarkan normalitas data, maka dapat dilihat bahwa garis kurva membentuk seperti gunung sehingga dapat dikatakan data terdistribusi dengan normal. 


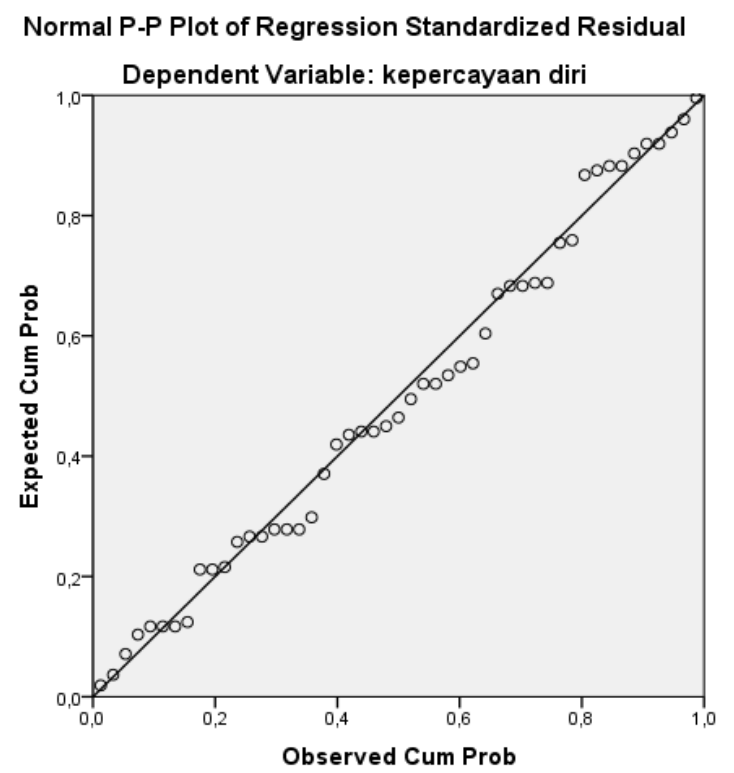

Gambar 1 Hasil Uji Normal P-P Plot

Berdasarkan hasil output grafik normalitas diatas (Normal P-P Plot of Regression Standardized Residual) dapat disimpulkan bahwa pada gambar tersebut menunjukkan penelitian ini memiliki data terdistribusi normal karena terdapat titik-titik yang menyebar disekitar garis diagonal, serta penyebarannya mengikuti arah garis diagonal tersebut. Hal ini menunjukkan bahwa model regresi layak dipakai karena memenuhi asumsi normalitas.

Mengenai hubungan antara variabel $\mathrm{X}$ dengan variabel $\mathrm{Y}$ juga memiliki hubungan yang linier. Hal ini dapat diketahui bahwa nilai signifikansi pada Deviation from Linierity sebesar 0,922. Karena nilai signifikansi lebih besar dari $0,05(0,922>0,05)$, maka dapat disimpulkan bahwa antara variabel perilaku bullying dan kepercayaan diri terdapat hubungan yang linier. Dengan ini maka asumsi linieritas terpenuhi.

Untuk mengetahui hipotesis yang diajukan telah terbukti kebenarannya, dan peneliti juga telah mengetahui hipotesis yang diterima atau yang ditolak. Maka dengan demikian peneliti menghitung koefisien korelasi dengan rumus $r$ product moment atau yang biasa disebut dengan $r$ hitung. Hal demikian dilakukan untuk mengetahui seberapa besarnya korelasi atau hubungan antara variabel $\mathrm{X}$ dengan variabel $\mathrm{Y}$ yang memiliki nilai signifikansi positif atau sebaliknya. Berdasarkan hasil analisis $\mathrm{r}$ product moment diperoleh nilai $\mathrm{r}$ hitung sebesar 0,690 kemudian nilai tersebut dikonsultasikan 
dengan nilai $\mathrm{r}$ tabel sebesar 0,281 pada $\mathrm{N}=49$ dengan taraf signifikan 5\%. Karena $r$ hitung $(0,690)>$ dari $r$ tabel $(0,281)$. Setelah itu dicocokkan dengan nilai interpretasi data, peneliti mengikuti teori menurut Sugiyono dalam (Priyatno SE,2016), maka dari nilai 0,690 dapat ditarik kesimpulan bahwa nilai tersebut terdapat pada baris keempat, yang artinya dari variabel $\mathrm{X}$ dengan variabel $\mathrm{Y}$ memiliki hubungan yang positif yang kuat.

Setelah itu untuk mengetahui tingkat signifikasi antara variabel $\mathrm{X}$ dan variabel $\mathrm{Y}$, maka hal tersebut dikuatkan dengan menggunakan $\mathrm{t}$ hitung dengan rumus berikut:

$$
\begin{aligned}
\text { Rumus t tabel } & =(\mathrm{a} / 2 ; \mathrm{n}-1-\mathrm{k}) \\
\text { Jadi t table } & =(0,05 / 2 ; 49-1-1) \\
\text { T tabel } & =(0,025 ; 47) \\
& =2,011
\end{aligned}
$$

Berdasarkan hasil diatas diketahui nilai t hitung 6,531 dan nilai t tabel sebesar 2,011. Hal tersebut menunjukkan bahwa perilaku bullying menunjukan nilai $\mathrm{t}$ hitung positif sebesar 6,531 > t tabel 2,011 dan nilai signifikan sebesar 0,000 $<0,05$ artinya Ho ditolak dan Ha diterima. Maka dapat disimpulkan bahwa perilaku bullying dapat berpengaruh secara signifikan terhadap kepercayaan diri siswa.

Kemudian langkah selannjutnya yaitu mencari tau seberapa besar konstribusi dari variabel X (bullying) terhadap variabel Y (kepercayaan diri siswa), maka peneliti mengitungnya dengan menggunakan koefisien determinasi yang mendapatkan hasil sebesar $47,61 \%$ sumbangan pengaruhnya dari perilaku bullying terhadap kepercayaan diri siswa dapat berlaku pada populasi dimana peneliti menjadikan 49 siswa tersebut sebagai sampel.

Maka dapat disimpulkan bahwa Hipotesis Alternatif $(\mathrm{Ha})$ diterima dan Hipotesis Nol (H0) ditolak, karena dari hasil perhitunggan terdapat pengaruh yang posititf antara variabel $\mathrm{X}$ dengan variabel $\mathrm{Y}$. Dapat dilihat hasil $\mathrm{r}$ hitung sebesar 0,690 kemudian t hitung sebesar 6,531 serta dapat diketahui bahwa dari perilaku bullying terhadap kepercayaan diri siswa memiliki sumbangan pengaruhnya sebesar $47,61 \%$ terhadap populasi, hal tersebut dapat dibuktikan dengan hasil uji pada sampel yang berjumlah 49 siswa.

\section{SIMPULAN}

Berdasarkan hasil analisa yang diperoleh dan telah diuraikan pada pembahasan sebelumnya oleh peneliti mengenai pengaruh dari perilaku bullying terhadap kepercayaan diri siswa kelas VIII di MT's Esa Nusa Islamic School Tangerang, maka dapat disimpulkan beberapa yang berkenaan dengan permasalahan yang dibahas yaitu: 
1. Tingkat Perundungan (perilaku bullying) pada siswa kelas VIII MTs Esa Nusa Islamic School Tangerang Tahun ajaran 2019-2020 tergolong dalam kategori kuat antara variabel Perilaku Bullying $(\mathrm{X})$ dengan variabel Kepercayaan Diri Siswa (Y) yang ditujukan dari hasil analisis korelasi dengan skor $\mathrm{r}$ hitung 0,690 terdapat korelasi positif. Menurut Sugiyono bahwa "interval koefisien 0,600 -0,799 termasuk kedalam kategori kuat". Dan tingkat persentase perilaku bullying terhadap kepercayaan diri siswa sebesar $47 \%$, hal tersebut hasil dari analisis koefisien determinasi $(\mathrm{r} 2)=0,6902=$ 0,476 atau 47,6\%, Maka peneliti menyimpulkan bahwa variabel perilaku bullying memberikan kontribusi kepada kepercayaan diri siswa sebesar 47,6\% dan sisanya sebesar 52,4\% dipengaruhi oleh faktor lain.

2. Terdapat pengaruh yang kuat antara variabel $\mathrm{x}$ dengan $\mathrm{y}$, Hasil Pengujian Hipotesis perilaku bullying dengan kepercayaan diri maka diperoleh hasil $r$ hitung $(0,690)>r$ tabel $(0,281)$ hal tersebut dapat diartikan bahwasannya variabel $\mathrm{x}$ dapat bepengaruh terhadap variabel y secara signifikan dengan memperoleh hasil analisis t hitung sebesar 6,531 > t tabel 2,011 dan nilai signifikan sebesar $0,000<0,05$ artinya Ho ditolak dan $\mathrm{Ha}$ diterima.

\section{DAFTAR PUSTAKA}

Adhiatma, W., \& Christianto, L. P. (2019). Suara Psikologi: Untuk Insan Indonesia. Penerbit Unika Atma Jaya Jakarta.

Nurdin, N. (2019). Generasi Emas Santri Zaman Now. PT. Elex Media Komputindo.

Zakiyah, E. Z., Humaedi, S., \& Santoso, M. B. (2017). Faktor yang mempengaruhi remaja dalam melakukan bullying. Prosiding Penelitian Dan Pengabdian Kepada Masyarakat, 4(2), 327. 